\title{
Double acute appendicitis in appendical duplication
}

\author{
Apendiks duplikasyonunda çift akut apandisit
}

\author{
Semra TUTCU ŞAHIN, ${ }^{1}$ Yamaç ERHAN, ${ }^{2}$ Hasan AYDEDE ${ }^{2}$
}

Duplication of the vermiform appendix is a rare congenital abnormality and usually found incidentally during laparotomy. The Modified Cave-Wallbridge classification is used to describe the location of the appendixes in relation to each other and to the cecum as well as the extent of the duplication. We report a 45-year-old patient who underwent laparotomy for acute abdominal pain. The operative finding was double acute appendicitis in appendical duplication. The appendixes were removed separately, as it was type B duplication. Since appendectomy is the most common abdominal operation, all surgeons should keep this rare clinical entity in mind.

Key Words: Appendicitis; duplication; vermiform appendix.
Appendiks vemiformis duplikasyonu nadir bir doğumsal anomalidir ve genellikle laparotomi esnasında tesadüfen saptanır. Apendikslerin birinin diğerine ve çekuma göre lokalizasyonunu tanımlamada ve aynı zamanda duplikasyonun boyutunu göstermede modifiye Cave ve Wallbridge sınıflaması kullanılır. Bu yazıda akut karın ağrısı nedeniyle laparotomi uygulanan 45 yaşında bir hasta sunuldu. Operasyon bulguları, apendiks duplikasyonu ile birlikte çift akut apandisit şeklinde idi. Tip B duplikasyon olması nedeniyle apendiksler ayrı ayrı alındı. Apendektomi en sık uygulanan abdominal cerrahi olması nedeniyle tüm cerrahlar bu nadir klinik antiteyi akılda tutmalıdırlar.

Anahtar Sözcükler: Apandisit; duplikasyon; appendiks vemiformis.
Appendical duplication is a rare abnormality, with an estimated incidence of $0.004 \%$ among patients undergoing appendectomy. ${ }^{[1,2]}$

We report a case of appendical duplication presented with double acute appendicitis.

\section{CASE REPORT}

A 45-year-old male presented with right lower quadrant pain, anorexia, nausea, and vomiting. The pain started in the epigastric region three days ago, and then intensified in severity with migration to the right lower quadrant. On physical examination, rigidity and rebound tenderness were noted in the right lower quadrant. The patient was febrile and tachycardic. White blood cell count was $21900 / \mathrm{mm}^{3}$. Other laboratory values were normal. Plain abdomen and chest X-rays appeared normal. Pelvic ultrasound in the emergency suite showed minimal periappendicular fluid and a non-peristaltic, non-compressible tubular structure with a diameter of $10 \mathrm{~mm}$.
McBurney incision was extended with the help of several retractors for optimal display of the surgical region, as shown in Figure 1. During exploration through the McBurney incision, a small amount of inflammatory fluid was noted. After cecal mobilization, two appendixes were seen: one on the corner where the taenia coli converge, and the other just next to it, with two separate bases. They shared the same mesoappendix, and both were erectile, hyperemic and inflamed; however, one was gangrenous and showed serosal necrosis (Figs. 1, 2). Routine appendectomy was performed for each. The postoperative period was uneventful, and the patient was discharged on the 3rd postoperative day.

On pathological examination, the appendixes measured $5 \times 0.7 \mathrm{~cm}$ and $8 \times 0.8 \mathrm{~cm}$. The lumen of the first was obstructed completely with fecalith resulting in serosal necrosis, whereas the other still had a $2 \mathrm{~mm}$ luminal passage despite the fecalith. Both appendix-
${ }^{1}$ Avukat Cengiz Gökcek State Hospital, Gaziantep; ${ }^{2}$ Department of General Surgery, Celal Bayar University Faculty of Medicine, Manisa, Turkey.
${ }^{1}$ Avukat Cengiz Gökçek Devlet Hastanesi, Gaziantep

${ }^{2}$ Celal Bayar Üniversitesi Tıp Fakültesi, Genel Cerrahi Anabilim Dalı, Manisa. 


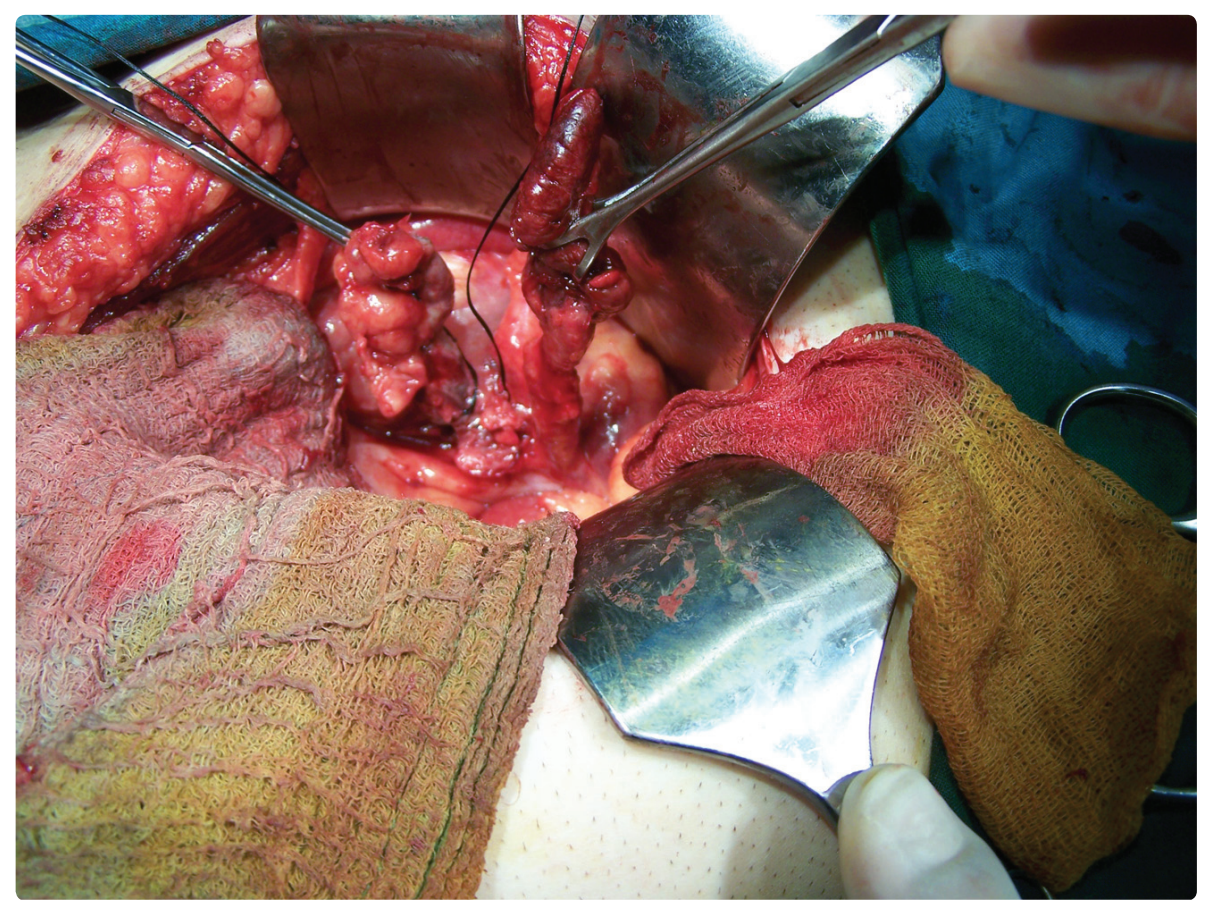

Fig. 1. Two appendixes share the same mesoappendix with different openings to the cecum. (Color figure can be viewed in the online issue, which is available at www.tjtes.org).

es had lymphoid tissues infiltrated predominantly by neutrophils.

\section{DISCUSSION}

Duplicated appendix vermiformis is a quite uncommon entity, believed to be seen in 1 in 25000 appendectomies. ${ }^{[1,2]}$ Cave and Wallbridge classified appendical duplication by their anatomical localization into three groups. Type A refers to incomplete duplication, where both appendixes arise from a common base from the cecum. Type B is the complete duplication, where one appendix is found in the usual location, where the taenia coli converge, while the localization of the other varies. Duplication of the cecum is classified as type $\mathrm{C}$, where each cecum has its own appendix. ${ }^{[3-5]}$ Mesko et al. ${ }^{[4]}$ described one appendix connected to the cecum with two openings, horseshoe appendix, which can be classified as type D. In our case, two appendixes sharing the same mesoappendix were found next to each other, and thus were classified as type B duplication.

The majority of duplicated appendixes are believed to be silent and only discovered when one of them becomes inflamed. ${ }^{[3-5]}$ Our patient was 45 years old and had never experienced any symptoms regarding appendical duplication. Both appendixes appeared inflamed at the time of the operation.

It has been mentioned in the literature in a few reports that although barium enema may be helpful in the radiological diagnosis, the exact diagnosis can only be made during the operation and postoperative pathological examination. All these anomalies are of great practical importance, and a surgeon must bear them in mind during an operation. They also carry legal importance in cases where repeated exploratory laparotomy reveals a "previously removed" vermiform appendix. ${ }^{[6]}$ During the first operation, insufficient exploration may result in overlooking the second appendix. In the case of appendicitis at a later time, the presence of an appendectomy history may cause a delay in the diagnosis and the differential diagnosis for appendicitis, which can cause some complications and medicolegal problems.

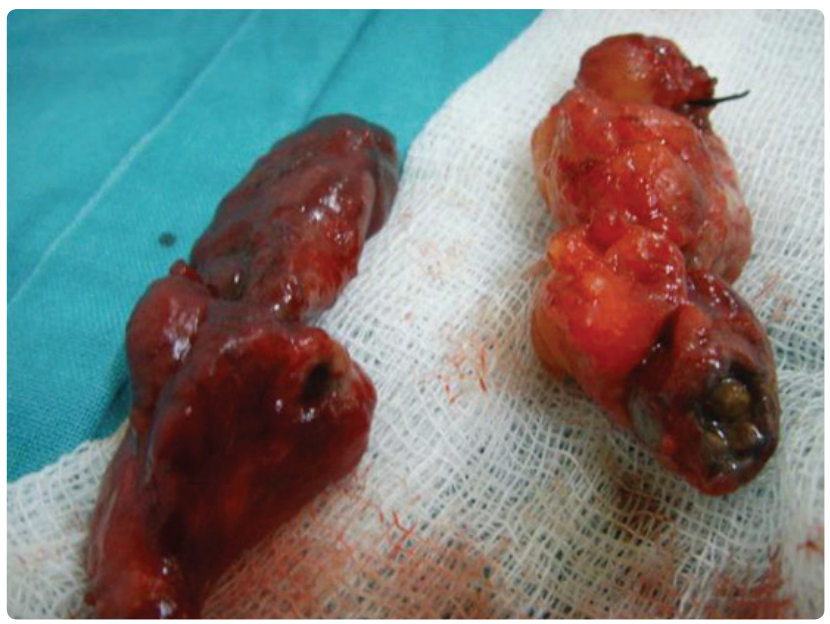

Fig. 2. Gangrenous appendix (left) and fecaliths obstructing the lumen (right). Note each appendix has its own lumen.

(Color figure can be viewed in the online issue, which is available at www.tjtes.org). 
Although seen rarely, duplication of the appendix should be kept in mind since appendectomy is the most common abdominal operation. During routine appendectomy, the cecum should be well mobilized to visualize any kind of possible duplication.

Conflict-of-interest issues regarding the authorship or article: None declared.

\section{REFERENCES}

1. Travis JR, Weppner JL, Paugh JC 2nd. Duplex vermiform appendix: case report of a ruptured second appendix. J Pediatr Surg 2008;43:1726-8.

2. Chew DK, Borromeo JR, Gabriel YA, Holgersen LO.
Duplication of the vermiform appendix. J Pediatr Surg 2000;35:617-8.

3. CaveAJ.Appendix Vermiformis Duplex. J Anat 1936;70:28392.

4. Mesko TW, Lugo R, Breitholtz T. Horseshoe anomaly of the appendix: a previously undescribed entity. Surgery 1989;106:563-6.

5. Kabay S, Yucel M, Yaylak F, Hacioglu A, Algin MC, Olgun EG, et al. Combined duplication of the colon and vermiform appendix in an adult patient. World J Gastroenterol 2008;14:641-3.

6. Yanar H, Ertekin C, Unal ES, Taviloglu K, Guloglu R, Mete $\mathrm{O}$. The case of acute appendicitis and appendiceal duplication. Acta Chir Belg 2004;104:736-8. 